18

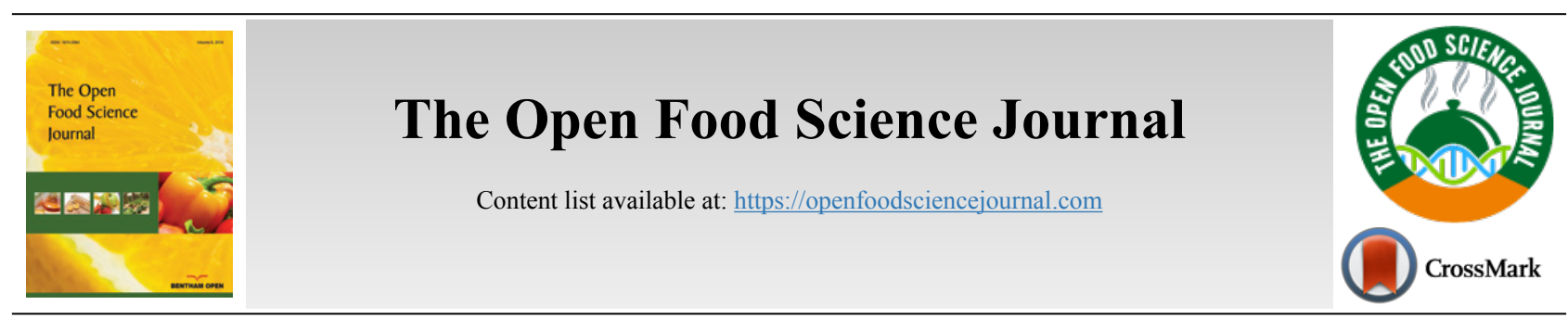

RESEARCH ARTICLE

\title{
A New Ready-To-Bake Seafood Meal Based on Pacific White Shrimp: Product Development, Cost Evaluation, Consumer Acceptability, and Shelf Life Stability
}

Sinthya Meire Lopes de Araújo and Alex Augusto Gonçalves*

Laboratory of Seafood Technology and Quality Control (LAPESC), Agricultural Sciences Center (CCA), Animal Sciences Department (DCA), Federal Rural University of Semi-Arid (UFERSA), Av. Francisco Mota, 572, Costa e Silva, 59625-900, Mossoró, RN, Brazil

\begin{abstract}
:
Background:

Considering that consumers are increasingly demanding and attentive to a healthy diet, while also looking for food that is easy to prepare, the objective of this work was to develop a new value-added product with Pacific white shrimp.

Methods:

Fresh shrimps were headless, eviscerated, cut, washed, immersed in brine ( $10 \% \mathrm{NaCl}+5 \%$ sodium tripolyphosphate $-\mathrm{STPP}, 30 \mathrm{~min})$, drained, weighed, immersed in sweet-sour sauce $(15 \mathrm{~min})$, drained, stuffed with cream cheese, weighed, vacuum packed, frozen $\left(-30^{\circ} \mathrm{C} / 24 \mathrm{~h}\right)$, and stored $\left(-18^{\circ} \mathrm{C}\right)$. Microbiological, centesimal composition and physico-chemical analyzes were performed for fresh and stuffed shrimp. Confirmed the microbiological safety, samples were baked $\left(180^{\circ} \mathrm{C}, 20 \mathrm{~min}\right)$ and sensorially evaluated. The shelf life study for the frozen stuffed shrimp was carried out during 180 days of storage $\left(-18^{\circ} \mathrm{C}\right)$ and at each 45 days, samples were withdrawn for microbiological and physico-chemical analyzes.

Results:

All parameters analyzed were within the limits of Brazilian legislation, which demonstrated the initial shrimp freshness, and hygienic health care. The overall acceptance test was 8.72 , the acceptability index of $96 \%$ and purchase intention of $82 \%$. The final cost per piece was lower and viable. The nutritional value was in accordance to the literature for this shrimp, and the physico-chemical results during the shelf life evaluation were stable.

\section{Conclusion:}

The vacuum packaging, and freezing storage, associated with hygienic-sanitary care promoted the stability of microbiological assessment, and physical-chemical properties, and the overall quality and safety product for the consumer, which can be a new alternative for the shrimp industry.
\end{abstract}

Keywords: New product, Value-added, Litopenaeus vannamei, Quality, Shelf life, Shrimp, Frozen food.

Article History Received: September 9, 2018 Revised: November 20, 2018

Accepted: November 21, 2018

\section{INTRODUCTION}

The seafood is an important source of food for mankind, especially as a source of high biological value proteins; so, it is not difficult to understand in the last decades, the increase in world seafood consumption, period marked by the awareness of human needs, the cult of well-being, health, and food safety $[1,2]$. Among the sea food species, crustaceans are the most

* Address correspondence to this author at the Laboratory of Seafood Technology and Quality Control (LAPESC), Agricultural Sciences Center (CCA), Animal Sciences Department (DCA), Federal University of Semi-Arid (UFERSA), Av. Francisco Mota, 572, Costa e Silva, 59625-900, Mossoró, RN, Brazil; Tel: + 558433178300r1419; Fax: +558433178361 ;

Mobile: + 5584 991713135; E-mail: alaugo@gmail.com valued products in the international food market (both in value and production) and much appreciated in several countries [3], especially the Pacific white shrimp (L. vannamei) which has grown in global demand, accounting for $80 \%$ of world shrimp production [4]. Due to its commercial production in many countries, and its industrialization in full growth, today, the shrimp consumers can have access to various forms of presentation, e.g. fresh, frozen, breaded, salted, smoked and canned. In addition, there are few choices of ready-to-cook products, in small portions and very varied preparations, available throughout the year, which facilitate the consumer's life under the aspect of practicality and availability [5].

Nowadays consumers are increasingly demanding and 
attentive to a healthy diet, at the same time as looking for food that is easy to prepare and convenient $[5,6]$. The shrimp is appreciated by the unique flavor and texture and can be served as appetizers or snacks. More importantly, in terms of human health, the high cholesterol content in shrimp is compensated by the low total lipids content and the predominance of polyunsaturated fatty acids [7]. In addition, the final presentation, in a more elaborate way [8], associated to the use of some natural spices, adding value to the product, can improve the final quality and make it more appreciated by consumers [9]. So, alternative forms of seafood processing, in addition to the usual ones (i.e. fresh, frozen, breaded or canned) such as new formulations, preprepared foods, and practical products should be offered.

Value aggregation in shrimp does not require the acquisition of large equipment and investments, as it can be represented by diversification in the presentation of products from local raw materials, such as coconut, cassava flour, and corn flour, low-cost products [10]. It is fundamental that the food professional glimpse a wonderful opportunity to develop researches for new products, suggesting innovative and profitable products, recognizing that the planning and the sustainability of shrimp are challenges that cannot be overlooked $[10,11]$. Thus, the present study proposes to develop a new valued added product (stuffed and ready to bake) with the Pacific white shrimp (Litopenaeus vannamei) using low cost ingredients and simple technology.

\section{MATERIALS AND METHODS}

\subsection{Raw Material}

The Pacific white shrimp (L. vannamei) were supplied by the shrimp farm Aquadelta Agroindustrial S.A. (Mossoró, RN, Brazil), slaughtered by thermal shock in water and ice (1: 1), immediately treated with $3 \%$ sodium metabisulphite, transported in isothermal boxes to the Laboratory of Seafood Technology and Quality Control (LAPESC / UFERSA) where they were immediately washed, weighed, counted (number of pieces per kilogram), and kept under refrigeration $\left(4^{\circ} \mathrm{C}\right)$ until the beginning of product development (time between slaughter and processing $<2 \mathrm{~h}$ ).

\subsection{Product Development}

The whole fresh shrimps (Fig. 1) were headless (leaving all shell from the first segment to the telson), washed (5 ppm chlorinated water), weighed, gutted, cut in the dorsal region (butterfly cut), and immersed in brine $(10 \% \mathrm{NaCl}+5 \%$ sodium tripolyphosphate STPP) for $30 \mathrm{~min}$, drained, immersed in the sweet-sour sauce (garlic, finger pepper, ginger, sugar, salt, rice vinegar and starch) for $15 \mathrm{~min}$ (for flavor absorption), drained, filled (manually) with cream cheese (Philadelphia Cream Cheese, Kraft Foods Brazil), weighed (yield calculation), vacuum packed, identified, frozen in ultrafreezer $\left(-30^{\circ} \mathrm{C}\right)$ and stored under freezer $\left(-18^{\circ} \mathrm{C}\right)$. The cost analysis of the formulation of the developed product was made based on the current market value of each ingredient used (shrimp, sweetsour sauce and cream cheese).

\subsection{Yield Calculation}

For each step during the product development, samples were weighed, to calculate the partial and overall yield of the final product. The methodology adopted was described by Gonçalves [12] according to the following Equations 1 and 2:

$$
\begin{aligned}
& \text { Partial Yield }(\%)=[(\mathrm{Pf}-\mathrm{Pi}) / \mathrm{Pi}] \times 100 \\
& \text { Overall Yield }(\%)=[(\mathrm{Pi}-\mathrm{Pf}) / \mathrm{Pi}] \times 100
\end{aligned}
$$

where: Pi = Initial weight (g); Pf = Final weight $(\mathrm{g})$

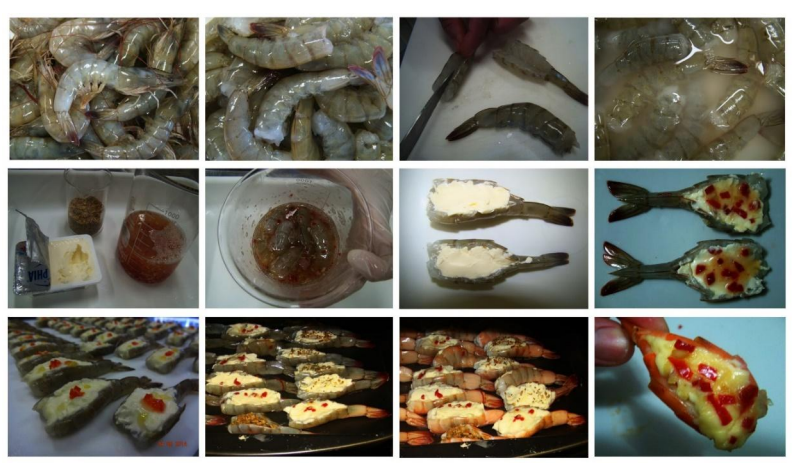

Fig. (1). Steps for the stuffed shrimp development.

\subsection{Centesimal Composition and Physicochemical Evaluation}

The centesimal composition (fresh shrimp and stuffed shrimp) was carried out through the analysis of moisture (Method 950.46), crude protein (Method 940.25), total lipids (Method 948.15), and ash (Method 938.08), according to AOAC's official methodology [13]. The $\mathrm{pH}$, nitrogen of total volatile bases (TVBN) and trimethylamine (TMA) determination were performed according to the methodology recommended by Laboratório Nacional de Referência Animal (LANARA) [14]. All analyzes were done in triplicate.

\subsection{Microbiological Analyzes}

The microbiological analyzes were carried out in accordance with Agência Nacional de Vigilância Sanitária (ANVISA, Brazil) - Resolução da Diretoria Colegiada (RDC) $12 / 2001$ [15] using the Brazilian official methodology (Instrução Normativa No. 62, de 26/08/2003) [16] The microorganisms analyzed for raw fresh shrimp were: total counts of mesophilic and psychrophilic bacteria, Salmonella $s p$., and coagulase-positive staphylococci; and for stuffed shrimp: total count of mesophilic and psychrophilic bacteria, Salmonella sp., coagulase positive staphylococci, and thermotolerant coliforms. All analyzes were performed at the Clinical and Immunological Analysis Center (CACIM, Mossoró, RN, Brazil).

\subsection{Sensory Analysis}

Confirmed the microbiological safety, samples baked in a preheated gas oven $\left(180^{\circ} \mathrm{C}\right)$ for $20 \mathrm{~min}$ and submitted to the sensory panel evaluation. The sensory analysis was performed with 50 untrained panelists $(32 \%$ men and $68 \%$ women, 
ranging in age from 18 to 48 years) who received still warm stuffed shrimp samples along with the evaluation form (structured hedonic scale of 9 points ranging from "extremely dislike" to "I liked very much"), which consisted in the subjective manifestation of the product tasted, demonstrating whether such a product pleases or displeases, whether it is accepted or not $[17,18]$. The acceptability index (IA) was calculated considering that $100 \%$ is the maximum score achieved by the product (stuffed shrimp) and the decision criterion for the IA to be well accepted is at least $70 \%[19,20]$. The consumer's buy intention was also evaluated using the Attitude Scale Test structured in five points that range from "I would certainly buy" to "I certainly would not buy" [17, 20].

\subsection{Product Stability During Frozen Storage}

The shelf life study of stuffed, frozen, vacuum-packed shrimp stored for 180 days at $-18^{\circ} \mathrm{C}$ was monitored every 45 days by microbiological (total count of mesophilic and psychrophilic bacteria, thermotolerant coliforms, Salmonella $s p$., and coagulase positive staphylococci) and physicochemical (pH, TVBN, TMA) analyzes.

\subsection{Statistical Analysis}

The means were compared using analysis of variance (ANOVA) and the effects were considered significant (by the Tukey test) when $p \leq 0.05$. All analyzes were performed by the XLSTAT Trial Version 2018.2 software (Addinsoft 1995-2018).

\section{RESULTS AND DISCUSSION}

\subsection{Product Yield and Formulation Cost}

The shrimp weighs at each step and the respective yields are shown in Table 1. For each 1,000g of shrimp, 43 units of shrimp were counted, which represents a shrimp with $\sim 23 \mathrm{~g}$ (per unit). After the headless shrimp step, the whole fresh shrimp lost $37.5 \%$ by weight, which represents a possibility of using this residue (head) for a new by-product development. After the brining step, $4.8 \%$ increase in weight was observed due to the incorporation of water by the presence of $\mathrm{NaCl}$ and
STPP (humectant food additive). The immersion in the sweetsour sauce, promoted the increment of $17 \%$ in weight, representing besides the weight gain, the improvement of the sensorial quality (tasty) by the incorporation of ingredients which can increase consumer acceptance. The cream cheese addition promotes an increase in weight of $15.70 \%$. The weight loss by the head removal step was not totally recovered by the increase in the final weight (resulting from filling with cream cheese), but to a certain extent, the losses (overall yield of $41.87 \%$ from headless shrimp) was minimized by the ingredients used. The same situation was also found during the developing a value-added product (e.g. butterfly breaded shrimp) with the same species [11].

The increase of $8.27 \%$ in the cost (comparing to the shrimp value) of the stuffed shrimp formulation (Table 2) was observed, and the final cost was R\$32.27 ( US\$ 7,70/kg raw fresh shrimp). However, when compared to ready-made dishes in restaurants and crustacean houses, this cost becomes lower than the average prices since dishes made with crustaceans reach the average value of R\$ 40.00 (US\$ 9.50) in local commerce. There are also no comparable products in the national market since most markets only sell shrimp in fresh/whole form or cooked or frozen.

Considering that this new product would be an ideal for sale per unit, and not per kilo, remembering the weight of shrimp of $23 \mathrm{~g}$, the cost per piece would reach the value of R \$ 0.75 (or US \$ 0.18 ). The value added having the differential of being a "baked product" (less caloric than the breaded and fried ones) the stuffed shrimp becomes a viable and best option. When compared to fried, the grilled or baked shrimp is presented as the best nutritional option, because it contains fewer lipids, saturated fat, and can provide the desirable in polyunsaturated [21].

\subsection{Nutritional and Physico-Chemical Analysis}

The results of the centesimal composition (moisture, protein, lipid, and ash) and physico-chemical (pH, TVBN and TMA) analyzes of fresh and stuffed shrimp are presented in Table 3.

Table 1. Partial yield (each step) and overall yield for the stuffed shrimp.

\begin{tabular}{|c|c|c|c|}
\hline STEPS & $\begin{array}{c}\text { Weight } \\
(\mathbf{g})\end{array}$ & $\begin{array}{c}\text { Yield } \\
(\mathbf{\%})\end{array}$ & $\begin{array}{c}\text { Gain (+) } \mid \text { Loss (-) } \\
\mathbf{( \% )}\end{array}$ \\
\hline Whole fresh shrimp & 1,000 & - & - \\
\hline Headless shrimp & 625 & 62.50 & -37.50 \\
\hline Shrimp after brine step & 655 & 104.80 & +4.80 \\
\hline Shrimp after sweet-sour sauce step & 766.33 & 117.00 & +17.00 \\
\hline Stuffed shrimp with cream cheese & 886.66 & 115.70 & +15.70 \\
\hline Overall yield* & - & 141.87 & +41.87 \\
\hline
\end{tabular}

*from headless shrimp

Table 2. Costs of the ingredients used for the stuffed shrimp development.

\begin{tabular}{|c|c|c|c|c|}
\hline Ingredient & Commercial quantity (g) & Price & $\begin{array}{c}\text { Used } \\
\text { quantity (g) }\end{array}$ & R\$ (US\$) \\
\hline Fresh whole shrimp & 1,000 & 24.00 & 1,000 & 24.00 \\
\hline
\end{tabular}


(Table 2) contd.....

\begin{tabular}{|c|c|c|c|}
\hline Ingle 2) contd.... & Commercial quantity (g) & Price & $\begin{array}{c}\text { Used } \\
\text { quantity (g) }\end{array}$ \\
\hline Cream cheese & 150 & 5.00 & 150 \\
\hline Saccharose (sugar) & 1,000 & 1,60 & 200 \\
\hline Rice vinegar & $750 \mathrm{~mL}$ ) & 3,00 & $150 \mathrm{~mL}$ \\
\hline Maize starch & 200 & 1,80 & 16 \\
\hline Peppers (10 units) & - & 1,50 & 0.32 \\
\hline Ginger & 1,000 & 13,00 & 0.14 \\
\hline Garlic & 43 & 0,50 & 16 \\
\hline TOTAL & & & 43 \\
\hline
\end{tabular}

Table 3. Results of centesimal and physico-chemical composition analysis of fresh raw shrimp and stuffed shrimp.

\begin{tabular}{|c|c|c|c|c|}
\hline \multirow{2}{*}{ Parameters } & \multicolumn{2}{|c|}{ Fresh raw shrimp } & \multicolumn{2}{c|}{ Stuffed shrimp } \\
\cline { 2 - 5 } & $\begin{array}{c}\text { Wet basis } \\
\text { (w.b.) }\end{array}$ & $\begin{array}{c}\text { Dry basis } \\
\text { (d.b.) }\end{array}$ & $\begin{array}{c}\text { Wet basis } \\
\text { (w.b.) }\end{array}$ & $\begin{array}{c}\text { Dry basis } \\
\text { (d.b.) }\end{array}$ \\
\hline Moisture (\%) & $73 \pm 1^{\mathrm{a}}$ & - & $66 \pm 2^{\mathrm{b}}$ & - \\
\hline Crude protein (\%) & $6.7 \pm 0.3^{\mathrm{a}}$ & $24 \pm 1^{*}$ & $5.2 \pm 0.7^{\mathrm{b}}$ & $15 \pm 2^{\dagger}$ \\
\hline Total lipids (\%) & $0.20 \pm 0.01^{\mathrm{a}}$ & $\begin{array}{c}0.70 \pm \\
0.01^{*}\end{array}$ & $4.7 \pm 0.9^{\mathrm{b}}$ & $14 \pm 3^{\dagger}$ \\
\hline Ash (\%) & $0.60 \pm 0.01^{\mathrm{a}}$ & $\begin{array}{c}2.30 \pm \\
0.03^{*}\end{array}$ & $0.40 \pm 0.02^{\mathrm{b}}$ & $1.2 \pm 0.6^{\dagger}$ \\
\hline $\mathrm{pH}$ & $7.7 \pm 0.1^{\mathrm{a}}$ & \multicolumn{2}{|c|}{$6.40 \pm 0.02^{\mathrm{b}}$} \\
\hline TVBN (mg/100g) & \multicolumn{2}{|c|}{$9.6 \pm 0.1^{\mathrm{a}}$} & \multicolumn{2}{c|}{$9.7 \pm 0.2^{\mathrm{a}}$} \\
\hline TMA (mg/100g) & \multicolumn{2}{|c|}{$1.8 \pm 0.1^{\mathrm{a}}$} & \multicolumn{2}{c|}{$1.9 \pm 0.1^{\mathrm{a}}$} \\
\hline
\end{tabular}

$(p>0.05)$ from each other at a significance level of $5 \%($ mean $\pm S D, n=3)$.

The moisture content for fresh shrimp (72.67\%) corroborates with that found in the scientific literature for $L$. vannamei [22]: $(72.8 \%$ organic farmed shrimp; $71.7 \%$ traditional farmed shrimp); however, lower than those found by other authors: 78\% [11], 77.2\% [23], 84.7\% [24], 74.1\% [25], and $77.9 \%$ [26]. The percentage of moisture content for stuffed shrimp (66.27\%) was lower and statistically different $(\mathrm{p}<0.05)$ when compared with the fresh one due to the incorporation, mainly of cream cheese, which increased the lipid content. Unfortunately, it was not found in the literature products like the one developed in the present research for comparison.

The protein content observed for fresh $(24 \%$, d.b.) was higher statistically different $(\mathrm{p}<0.05)$ comparing to stuffed shrimp (15.4\%, d.b.). Since cream cheese is more energetic than protein, this difference can be justified. The protein content was close to the white shrimp [22] from both organic $(23.7 \%)$ and traditional farm (25.3\%). Sriket et al. [23] evaluating the chemical composition of the monodon and vannamei species, observed lower protein content (19\% and $22 \%$, respectively). Gonçalves \& Gomes [11] also found lower values for fresh shrimp (19\%), and for breaded shrimp (13\%).

The lipids content for fresh raw shrimp was $0.7 \%$ (d.b.), remaining between the range of values found in the literature, however, lower $(0.2 \%$ w.b.) than those found in the literature $0.3 \%$ [25] and $0.33 \%$ [11]; while Chirol [22] found higher values for both vannamei in traditional $(1.32 \%$, w.b.) and organic farm $(1.47 \%$, w.b.). For the stuffed shrimp, the lipid content was higher $(13.9 \%$, d.b.) and statistically different $(p<0.05)$ when comparing to the fresh shrimp. According to
Perry [27], dairy products, such as cream cheese, are rich in lipids, and according to the nutritional information table from the cream cheese manufacturer, the total fat $(8.1 \mathrm{~g}$ a portion of 30 grams) is higher and can contribute to the increment of lipid content in stuffed shrimp.

The ash content found was $2.3 \%$ (d.b.) for fresh raw shrimp and in accordance to those found for pink shrimp Parapenaeus longirostris (2.3\%) [24], and for L. vannamei from organic $(2.1 \%$, d.b.) [22], but higher than those from traditional farm $(1.6 \%$, d.b. $)$ [22]. Araujo et al. [25] also found a lower ash content $(1.5 \%$, d.b.) than those found in the present study, however, it should be noted that these authors analyzed the meat without the exoskeleton. Gonçalves \& Gomes [11] developing a value added product with $L$. vannamei, also found lower ash content $(1.6 \%$ d.b. fresh shrimp and $1.2 \%$ d.b. breaded shrimp). This difference of percentages can be justified because of the presence of the exoskeleton (from the first segment follow up to the telson). In addition, the exoskeleton of crustaceans is composed basically of calcium carbonate, which can lead, therefore, to a higher ash content. For the stuffed shrimp, the ash content found was lower $(1.24 \%$, d.b. $)$ and statistically different $(\mathrm{p}<0.05)$ compared to the fresh one, but closer to that found by Gonçalves \& Gomes [11], for breaded shrimp.

The $\mathrm{pH}$ drops statistically $(\mathrm{p}<0.05)$ from raw fresh shrimp (7.7) to the stuffed shrimp (6.4) and can be associated to the increment of cream cheese, which according to Phadungath [28] states that the cream cheese $\mathrm{pH}$ is between 4.4 and 4.9. Despite the drop in $\mathrm{pH}$, the results is in accordance with the $\mathrm{pH}$ limited as a parameter of freshness by Brazilian legislation [29] for raw fresh shrimp (7.85) and also, corroborated with the low values of TBVN and TMA (and without statically difference, $p>0.05$, between fresh and stuffed shrimp), being also in accordance with the current legislation. It is emphasized that the shrimp was treated with sodium metabisulfite immediately after slaughter and with the food grade humectant additive (STPP) during the processing, which may result in a slight increase in $\mathrm{pH}$ value. In addition, the way in which shrimp is handled, from capture to consumer arrival, determines the intensity with which they present the enzymatic, oxidative and microbiological changes $[2,30]$. The speed with which each of these changes develops depends on how the basic principles of conservation, hygiene, cold chain and capture methods were applied [2]. In the present study, all hygienic-sanitary care was done thinking mainly about the quality of the final product and the safety of the consumer. 


\subsection{Microbiological Analysis}

No growth of microorganisms was observed in fresh raw and stuffed shrimp, demonstrating that all technological processes were carried out within the hygienic-sanitary standards since collection at the farm, guaranteeing the perfect cold chain along the transport, and handling, and the use of chlorinated water in each washing step. Honda [31] states that inadequate storage temperature during transportation, storage, and marketing contributes greatly to the multiplication of microorganisms present in shrimp. In addition, the use of gloves, masks by the manipulators, as well as the hygiene of utensils and workbench, and the use of sodium metabisulphite after the slaughter, and the brining process $(\mathrm{NaCl}+\mathrm{STPP})$ corroborated with the result and leave the product apt and safe for consumption (sensory analysis) and suitable for later storage (shelf life study).

\subsection{Sensory Analysis}

The average score in the Hedonic Scale for the stuffed shrimp was 8.72 which represents the scale between "I liked very much" and "I liked it extremely". Eighty-six percent were attributed as "I liked extremely", demonstrating an excellent acceptability, which corroborates with the Acceptability Index (AI) calculated of $96.9 \%$ (excellent acceptance of the product among the tasters). This result was higher when compared to those value-added products found in the literature: butterfly breaded shrimp (87.8\%) [11], and smoked fish fillets (82.2\%) [32]. On the other hand, Fernandes et al. [33] evaluating the cake made with shrimp cephalothorax meal showed medium acceptance, with average scores above 7.0 ("I liked moderately"). Despite the divergence between acceptance values found in the literature for several products, the product acceptance varies with living standards and cultural basis, and demonstrates the consumer's reaction to various aspects, such as price, age, hygiene, place of consumption, and not only if whether or not it pleased the product $[33,34]$. In this sense, the purchase intention for stuffed shrimp corresponded to $82 \%$ ("Surely I would buy"), going to $14 \%$ ("Probably I would buy") and 4\% ("Maybe I would buy / maybe I would not buy"). The percentage of $82 \%$ ("surely I would buy") indicated that the product was well accepted by consumers, suggesting that there is potential for marketing.

\subsection{Product Stability (Shelf Life)}

The microbiological analysis of food is a prerequisite for microbial safety management [35]. As expected, the results of the microbiological analyzes showed absence of the analyzed microorganisms (total mesophilic and psychrophilic counts, Salmonella sp., coagulase positive staphylococci and thermotolerant coliform) at the beginning of storage (Time Zero), and remained unchanged throughout the evaluated period, demonstrating that the hygienic-sanitary quality at the beginning of the study corroborated with its subsequent microbiological stability throughout the 180 days of storage.

The results of the physico-chemical analyze of the stuffed shrimp along the 180 days of storage $\left(-18^{\circ} \mathrm{C}\right)$ are presented in Table 4. No significative difference $(p>0.05)$ was observed in all parameters evaluated during the 180 days of storage. The
$\mathrm{pH}$ values for the stuffed shrimp remained stable throughout the storage period, and below the legal limits [29] for shrimp freshness (7.85), which corroborates with the results of the lower TVBN, TMA and microbiological analyzes; however, differed from the results of the shelf life of frozen shrimp (Macrobrachium rosenbergii) at different temperatures: the initial $\mathrm{pH}$ of 6.95 increased to $7.93\left(-12^{\circ} \mathrm{C}\right)$ in 39 days and after to $7.85\left(-15^{\circ} \mathrm{C}\right)$ in 74 days [36].

The results for TVBN and TMA remained stable over the storage period, and below the legal limits for freshness, i.e., $<30 \mathrm{mg} / 100 \mathrm{~g}$ and $<5 \mathrm{mg} / 100 \mathrm{~g}$, respectively. According to Soares \& Gonçalves [30], the total volatile bases represent the set of nitrogenous bases, such as ammonia, trimethylamine, dimethylamine, monomethyl amine, putrescine, cadaverine and spermidine, normally present in deteriorated fish and, according to [37], the production of TBVN during seafood storage is a result of the action of tissue enzymes and microbiological activity. Hocaoglu [38] observed in frozen shrimp $\left(-18^{\circ} \mathrm{C}\right) 12.33 \mathrm{mg} / 100 \mathrm{~g}$ and Oliveira et al. [39] observed $14.57 \mathrm{mg} / 100 \mathrm{~g}$. Tsironi et al. [36] detected values of up to $25 \mathrm{mg} / 100 \mathrm{~g}$ after eight months of frozen storage $\left(-15^{\circ} \mathrm{C}\right)$, and Bono et al. [40] observed results up to $86 \mathrm{mg} / 100 \mathrm{~g}$ after eight months of storage. As the initial microbiological quality of the stuffed shrimp was excellent (i.e. absent), no degradative chemical changes from microorganisms during frozen storage can be achieved, which corroborated the physicochemical stability of the product throughout the storage time.

Table 4. Physico-chemical results of frozen stuffed shrimp stored at $-18^{\circ} \mathrm{C}$ for 180 days.

\begin{tabular}{|c|c|c|c|c|c|}
\hline \multirow{2}{*}{ Parameters } & \multicolumn{5}{|c|}{ Storage days } \\
\cline { 2 - 6 } & $\mathbf{0}$ & $\mathbf{4 5}$ & $\mathbf{9 0}$ & $\mathbf{1 3 5}$ & $\mathbf{1 8 0}$ \\
\hline $\mathrm{pH}$ & $\begin{array}{c}6.40 \pm \\
0.02\end{array}$ & $6.3 \pm 0.1$ & $6.5 \pm 0.2$ & $6.5 \pm 0.2$ & $6.2 \pm 0.1$ \\
\hline TVBN (mg/100g) & $9.7 \pm 0.2$ & $\begin{array}{c}10.1 \pm \\
0.3\end{array}$ & $\begin{array}{c}10.4 \pm \\
0.3\end{array}$ & $\begin{array}{c}10.0 \pm \\
0.2\end{array}$ & $9.9 \pm 0.2$ \\
\hline TMA (mg/100g) & $1.9 \pm 0.1$ & $2 \pm 0.1$ & $1.8 \pm 0.1$ & $1.7 \pm 0.1$ & $1.8 \pm 0.1$ \\
\hline T0 = time zero day; T45 = time 45 days; T90 $=$ time 90 days; $\mathrm{T} 135=$ \\
time 135 days; T180 = time 180 days; (mean $\pm \mathrm{SD}, \mathrm{n}=3)$ \\
\hline
\end{tabular}

\section{CONCLUSION}

The incorporation of the sweet-sour sauce and the cream cheese gave the partial recovery $(\sim 70 \%)$ of the losses (yield) obtained during the heading process. The product developed in this study (stuffed shrimp ready-to-bake) is easy to prepare, quick and dispenses with the use of oil for frying. The product had a relatively low cost per unit (R\$ 0.75 or US\$ 0.18 ). The results of chemical composition demonstrated a good nutritional value for the product developed. The stuffed shrimp presented excellent acceptability (96.89\%) and purchase (buy) intention $(82 \%)$. The vacuum packaging, storage at $-18^{\circ} \mathrm{C}$ for 180 days ( 6 months), associated with hygienic-sanitary care during processing promoted the physical-chemical and microbiological stability, and thus a safe and quality product for the consumer. The economic evaluation and a higher storage time for the shelf life are suggested to ensure the stability in more than 6 months, thus providing greater visibility and viability of this product for the industry. 


\section{ETHICS APPROVAL AND CONSENT TO PARTICIPATE}

Not applicable.

\section{HUMAN AND ANIMAL RIGHTS}

No animals/humans were used for studies that are the basis of this research.

\section{CONSENT FOR PUBLICATION}

Not applicable.

\section{CONFLICT OF INTEREST}

The authors confirm that there are no known conflicts of interest associated with this publication and there has been no significant financial support for this work that could have influenced its outcome.

\section{ACKNOWLEDGEMENTS}

Declared none.

\section{REFERENCES}

[1] Barbosa JM. Fraudação na comercialização do pescado. Acta of Fisheries and Aquatic Resources 2015; 3(2): 89-99.

[2] Gonçalves AA. Tecnologia do pescado: Ciência, tecnologia, inovação e legislação, Atheneu, São Paulo, SP, Brazil. 2011; p. 608.

[3] Oliveira ARM. Efeito antimelanósico da acerola e metabissulfito de associado à embalagem em atmosfera modificada sobre a qualidade do camarão branco Litopenaeus vannamei. Master thesis. Universidade Federal Rural do Semi-Árido. Mossoró, RN, Brazil 2013; 102.

[4] Jescovitch LN, Ullman C, Rhodes M, Davis DA. Effects of different feed management treatments on water quality for Pacific white shrimp Litopenaeus vannamei. Aquacult Res 2017; 49(1): 526-31. [http://dx.doi.org/10.1111/are.13483]

[5] Rocha MMRM, Menegassi M, Gonçalves AA. Benefícios do consumo de camarão para a saúde. Revista da ABCC 2011; 13(1): 66-70.

[6] Messias CR, Konopka DN, Biassi DC, et al. Treinamento e caracterização sensorial de formulações de fishburger elaboradas à base de subprodutos da filetagem de tilápia (Oreochromis niloticus). Brazilian Journal of Food Research 2016; 7(2): 125-42.

[7] Norhana MNW, Poole SE, Deeth HC, Dykes GA. Prevalence, persistence, and control of Salmonella and Listeria in shrimp and shrimp products: A review. Food Control 2010; 21: 343-61.

[http://dx.doi.org/10.1016/j.foodcont.2009.06.020]

[8] Gonçalves AA, Santos TCL. The effects of vacuum and modified atmosphere packaging on quality changes in seasoned cobia (Rachycentron canadum) sticks stored under refrigeration. Braz J Food Technol 2018; 21: e2017029.

[http://dx.doi.org/10.1590/1981-6723.02917]

[9] Rustad T, Storrø I, Slizyte R. Possibilities for the utilization of marine by-products. Int J Food Sci Technol 2011; 46(10): 2001-14. [http://dx.doi.org/10.1111/j.1365-2621.2011.02736.x]

[10] Rocha IP. Shrimp aquaculture grows in Brazil. Global Aquaculture Advocate 2003; pp. 71-3.

[11] Gonçalves AA, Gomes PA. Desenvolvimento de um produto de valor agregado: camarão empanado corte butterfly. Revista Brasileira de Engenharia de Pesca 2008; 3(1): 62-75.

[12] Gonçalves AA. Estudo do processo de congelamento do camarão associado ao uso do aditivo fosfato. Porto Alegre: Universidade Federal do Rio Grande do Sul, Doctoral Thesis (Doutorado em Engenharia de Produção) 2005; 170.

[13] Official Methods of Analysis of Aoac international (2011) $18^{\text {th }}$ Ed., Aoac international, Gaithersburg, MD, USA, Official Method 950.46; 940.25; 948.15; 938.08

[14] Brazil Ministério da Agricultura, Pecuária e Abastecimento (MAPA), Secretaria Nacional de Defesa Agropecuária (SDA), Laboratório Nacional de Referência Animal (LANARA) Métodos analíticos oficiais para o controle de Produtos de Origem Animal e seus ingredientes II - Métodos físicos e químicos. Brasília: LANARA 1981.
[15] Brazil. Ministério da Agricultura, Pecuária e Abastecimento (MAPA), Instrução Normativa $\mathrm{N}^{\circ} 62$, de 26 de agosto de 2003. Oficializa os Métodos Analíticos Oficiais para Análises Microbiológicas para Controle de Produtos de Origem Animal e Água. Diário Oficial da União, Brasília, 18/09/2003, Seção 1, Página 14.

[16] Stone H, Sidel JL. Sensory Evaluation Practices. London: Academic Press 2004; p. 311.

[17] Pizato S, Kraieski J, Sarmento C, Prentice C. Avaliação da qualidade tecnológica apresentada por tilápia do Nilo (Oreochromis niloticus) enlatada. Semin Cienc Agrar 2012; 33(2): 667-74. [http://dx.doi.org/10.5433/1679-0359.2012v33n2]

[18] Teixeira E, Meinert EM, Barbetta PA. Análise Sensorial de Alimentos. Florianópolis, SC, Brazil: Editora da UFSC 1987; p. 180.

[19] Dutcosky SD. Análise sensorial de alimentos. $2^{\text {nd }}$ ed. Curitiba, PR, Brazil: Champagnat 2007; p. 239.

[20] Scherr C, Ribeiro JP. Influência do modo de preparo de alimentos na prevenção da aterosclerose. Rev Assoc Med Bras (1992) 2013; 59(2): 148-54.

[http://dx.doi.org/10.1016/j.ramb.2012.10.001] [PMID: 23582556]

[21] Chirol KA. Rendimento, composição química e perfil lipídico do camarão Litopenaeus vannamei de cultivo orgânico e convencional. Master Thesis (Mestre em Ciência e Tecnologia de Alimentos Universidade Federal da Paraíba), João Pessoa, PB, Brazil 2007; 97.

[22] Sriket P, Benjakul S, Visessanguan W, Kijroongrojana K. Comparative studies on chemical composition and thermal properties of black tiger shrimp (Penaeus monodon) and white shrimp (Penaeus vannamei) meats. Food Chem 2007; 103: 1199-207. [http://dx.doi.org/10.1016/j.foodchem.2006.10.039]

[23] Cadun A, Kışla D, Çaklı Ş. Marination of deep-water pink shrimp with rosemary extract and the determination of its shelf-life. Food Chem 2008; 109(1): 81-7.

[http://dx.doi.org/10.1016/j.foodchem.2007.12.021] [PMID: 260542 67]

[24] Araujo DFS, Silvestre DD, Damasceno KSFSC, Pedrosa LFC, Seabra LMAJ. Composição centesimal e teor de colesterol do camarão branco do Pacífico. Cienc Rural 2012; 42(6): 1130-3.

[http://dx.doi.org/10.1590/S0103-84782012000600029]

[25] Lira GM, Silva MCD, Silva KWB, et al. Avaliação da qualidade físico-química e microbiológica do camarão espigão (Xiphopenaeus kroyeri, Heller, 1862) in natura e defumado. Bol Cent Pesqui Process Aliment 2013; 31(1): 151-60.

[http://dx.doi.org/10.5380/cep.v31i1.32717]

[26] Perry KSP. Queijos: Aspectos químicos, bioquímicos e microbiológicos. Quim Nova 2004; 27(2): 293-300. [http://dx.doi.org/10.1590/S0100-40422004000200020]

[27] Phadungath C. Cream cheese products: A review. Songklanakarin J Sci Technol 2005; 27(1): 191-9.

[28] Brazil. Ministério da Agricultura, Pecuária e Abastecimento (MAPA). Decreto $\mathrm{n}^{\circ}$ 9.013, de 29 de março de 2017, aprova o novo Regulamento de Inspeção Industrial e Sanitária de Produtos de Origem Animal - RIISPOA. Brasília, DF: Diário Oficial da União, 30/03/2017, Seção 1, No 62 3-27.

[29] Soares KMP, Gonçalves AA. Qualidade e segurança do pescado. Rev Inst Adolfo Lutz 2012; 71(1): 1-10.

[30] Honda SN. Avaliação microbiológica do camarão da Amazônia (Macrobrachium amazonicum) e sua relação com o ambiente de criação na carcinicultura. Master Thesis (Mestrado em Aquicultura Universidade Estadual Paulista), Jaboticabal, SP, Brazil 2012; 66.

[31] Ribeiro SCA, Tobinaga S. Avaliação sensorial de filés de matrinchã (Brycon cephalus) processados por métodos combinados. Rev Bras Prod Agroind 2002; 4(2): 101-6.

[http://dx.doi.org/10.15871/1517-8595/rbpa.v4n2]

[32] Fernandes TM, Silva JA, Silva AHA, Cavalheiro JMO, Conceição ML. Flour production from shrimp by-products and sensory evaluation of flour-based products. Pesqui Agropecu Bras 2013; 48(8): 962-7. [http://dx.doi.org/10.1590/S0100-204X2013000800022]

[33] Teixeira LV. Análise sensorial na indústria de alimentos. Rev Inst Laticínios Cândido Tostes 2009; 366(64): 12-21.

[34] Zhang Z, Xiao L, Lou Y, et al. Development of a multiplex real-time PCR method for simultaneous detection of Vibrio parahaemolyticus, Listeria monocytogenes and Salmonella sp. in raw shrimp. Food Control 2015; 51: 31-6.

[http://dx.doi.org/10.1016/j.foodcont.2014.11.007]

[35] Tsironi T, Dermesonlouogloua E, Giannakouroua M, Taoukis P. Shelf life modeling of frozen shrimp at variable temperature conditions. Food Sci Technol (Campinas) 2009; 42(2): 664-71.

[36] Kirschnik PG, Viegas EMM. Alterações na qualidade do camarão de 
água doce Macrobrachium rosenbergii durante estocagem em gelo. Food Sci Technol (Campinas) 2004; 24(3): 407-12.

[http://dx.doi.org/10.1590/S0101-20612004000300019]

[37] Hocaoglu A, Demirci AS, Gümüs T, Demirci M. Effects of gamma irradiation on chemical, microbial quality and shelf life of shrimp. Radiat Phys Chem 2012; 81(12): 1923-9.

[http://dx.doi.org/10.1016/j.radphyschem.2012.07.017]

[38] Oliveira VM, Freitas MQ, Clemente SCS, Mársico ET. Método do índice de qualidade (MIQ) desenvolvido para camarão (Litopenaeus vannamei) cultivado. Rev Cienc Vida 2009; 29(1): 60-71.

[39] Bono G, Gai F, Peiretti PG, et al. Chemical and nutritional characterisation of the Central Mediterranean Giant red shrimp (Aristaeomorpha foliacea): Influence of trophic and geographical factors on flesh quality. Food Chem 2012; 130(1): 104-10.

[http://dx.doi.org/10.1016/j.foodchem.2011.07.004] [PMID: 264342 69]

[40] Gonçalves AA. Produtos de valor agregado: Um desafio ou uma necessidade? Aquaculture Brasil 2018; 2018(11): 70-1.

\section{Lopes de Araújo and Gonçalves.}

This is an open access article distributed under the terms of the Creative Commons Attribution 4.0 International Public License (CC-BY 4.0), a copy of which is available at: (https://creativecommons.org/licenses/by/4.0/legalcode). This license permits unrestricted use, distribution, and reproduction in any medium, provided the original author and source are credited. 